\title{
Perception of freedom in leisure among substance users and nonusers
}

\author{
Diego Eugênio Roquette Godoy Almeida - Universidade Federal de São Paulo, São Paulo, Brasil \\ André Luiz. Monezi Andrade - Pontifícia Universidade Católica de Campinas, Campinas, Brasil \\ Fernanda Davidoff Cruz - Universidade Federal de São Paulo, São Paulo, Brasil \\ Denise de Micheli - Universidade Federal de São Paulo, São Paulo, Brasil
}

\begin{abstract}
The aim of this study was to verify that substance use among adolescents would be linked to perceptions of freedom in leisure. It was selected for convenience sampling 186 adolescents at Projeto Quixote in a public school in Guarulhos. It used as questionnaire Data Sociodemographic and Leisure, The Leisure Diagnostic Battery, version B (PLL) to measure Perceived Freedom in Leisure and Drug Use Screening Inventory for classification of substance use, all self-administered. Based on 165 reviews analyzed, the frequency of use of ecstasy and marijuana in the last month were related to higher rates of PLL. The number of substances used in the last month had no significant effect. These data suggest specific components of leisure related to the frequency of substance use, such as perceived control and need at leisure.

Keywords: leisure activities; adolescent; substance related-disorders; cccupational terapia ocupacional.
\end{abstract}

Percepção de liberdade no lazer entre usuários e não usuários de substâncias

\begin{abstract}
Resumo
O objetivo deste trabalho foi avaliar se o uso de substâncias entre adolescentes de estaria relacionado relacionado à percepção de liberdade no lazer (PLL). Selecionou-se por conveniência 186 adolescentes no Projeto Quixote e de uma escola estadual de Guarulhos. Utilizou-se o Questionário de Dados Sóciodemográficos e de Lazer, The Leisure Diagnostic Battery, version B (PLL) para mensurar a Percepção de Liberdade no Lazer, e o Drug Use Screening Inventory para classificação do uso de substâncias. Dentre as 165 avaliações analisadas, a frequência do uso de ecstasy e maconha no último mês relacionaram-se com maiores índices do PLL e o número de substâncias usadas no último mês não teve efeito significativo. Os dados indicaram que a frequência do uso de substâncias relaciona-se com subitens do PLL. Observou-se tendência ao aumento do PLL conforme o aumento do uso de substâncias.

Palavras-chave: atividades de lazer, adolescente, transtornos relacionados ao uso de substâncias, terapia ocupacional
\end{abstract}

La percepción de la libertad en el ócio entre usuarios y no usuarios de sustâncias

\begin{abstract}
Resumen
El objetivo de este estudio fue verificar que el uso de sustancias entre los adolescentes podría estar vinculada a la percepción de la libertad en el ocio. Fue seleccionado para el muestreo de conveniencia 186 adolescentes en Proyecto Quijote en una escuela pública de Guarulhos. Se utiliza como cuestionario de datos sociodemográficos y de ocio, la batería de diagnóstico Ocio, versión B (PLL) para medir la percepción de la Libertad en Ocio y Uso de Drogas Inventario de cribado para la clasificación del uso de sustancias, todos los auto-administrado. Basado en 165 comentarios analizan, la frecuencia de uso de éxtasis y marihuana en el último mes se relacionaron con mayores tasas de PLL. El número de sustancias utilizadas en el último mes no tuvo ningún efecto significativo. Estos datos sugieren componentes específicos de ocio relacionadas con la frecuencia de uso de sustancias, como el control percibido y necesitan en el ocio.

Palabras clave: actividades recreativas, adolescente, trastornos relacionados con sustâncias, libertad
\end{abstract}

Classic sociological studies define leisure from the release of productive, religious, domestic and political duties (Dumazedier, 2008). This definition, originated on modern times, began to influence the structure of modern life, after the industrial revolution. Although man has always enjoyed idleness in their affairs, it was during the industrial revolution that leisure was set as counterpoint to the long working hours. In addition to understanding leisure as an objective phenomenon it can also be seen as attitude or "state of mind". Neulinger (1990) states that of all the subjective determinants of leisure, such as pleasure, relaxation and well-being, we can highlight the perceived freedom in leisure (PFL) as the most important of them. Leisure can be studied from different categories, depending on the activities performed. Being considered an experience lived that occurs at any time during any activity depending on feelings and perceptions undertaken in this purpose (Witt \& Ellis, 1999).

Individuals who have a high degree of perceived freedom in leisure (PFL) participate in larger amounts of activities of interest and believe they are better able to control their own course of action, in addition to having high amounts of playfulness (Dumazedier, 
2008). In this sense, PFL levels are influenced from experienced interactions, and according to the model of Crawford, Jackson and Godbey (1987) there are three main types: intrapersonal, interpersonal and structural, and most researches focus on the latter (AkyldizMunusturlar \& Argan, 2016; Ertuzun, 2015; Leversen, Danielsen, Birkeland, \& Samdal, 2012).

The PFL is a motivational cognitive construct that takes in consideration some important questions on how to process this experience, such as: perceptions of needs, competence, control over the experience and leisure of involvement, as well as depth and emotional involvement perception (Witt \& Ellis, 1999). The first dimension refers to the perceived need which has been described as one of the components necessary to the leisure. Witt and Ellis (1999) attribute to leisure the function of meeting the catharsis needs, relaxation, compensation, socialization, novelty, stimulation and creative expression. If satisfied, it is possible to experience feelings of satisfaction and well-being.

Both the perceptions of depth and of emotional involvement are functional leisure components focused on the process through which individuals can experience shifts of consciousness. This state known as "flow of consciousness" or "flow" is studied by Mihaly Csikszentmihalyi that compares to the "peak experience" of Maslow (Csikszentmihalyi, 1992). The experience of this flow would lead to an immediate positive feedback, providing a sense of control and competence, low distractibility that would relieve the individual from usual fears, setting aside the fear of failure, and disappearing self-consciousness. The experience of flow has been explored in researches involving religious, tribal, sports and leisure rituals, for all these activities keep certain similarity between them regarding the status of "rapture from reality." On the other hand, the perception of competence is based in sense of self-efficacy to resolve a situation of practical life and in the belief that an individual has about their own capability to carry through, affecting their choices and the performance itself (Neulinger. 1990). The last dimension is the perception of control, described as the predisposition to perceive oneself as a causal agent in relation to their future (Appel-Silva, Wendt \& Argimon, 2010).

Some authors state that leisure is broad in meaning in the development process of adolescents, because it contributes to their autonomy, construction of identity and the establishment of social ties (Caldwell \& Witt, 2011; Leversen et al, 2012.). In the other hand, it can also be associated with risky sexual behavior and drug use, from recreational use (Pinheiro,
Andrade \& Demicheli, 2016; ter Bogt et al, 2012;. Van Havere, Vanderplasschen, Lammertyn, Broekaert, \& Bellis, 2011). In terms of substance use, the term recreational means sporadic consumption and low risk. Until its fourth edition, Diagnostic and Statistical Manual of Mental Disorders included a standard risk use, characterized by a pattern of use where there is physical or mental harm to health, without the criteria for dependence being filled. Now in its fifth edition, the criteria were revised and there are three diagnostic possibilities: mild, moderate or severe dependence, depending on the intensity and number of symptoms (Clark, Gillespie, Adkins, Kendler, \& Neale, 2016).

Despite the potential of recreational activities, there are few studies in the literature on the possible association between leisure-attitude and substance use. By way of example, in relation to sports, there is evidence linking modalities of exercise and sports to substance use. The pattern of use of a substance may vary according to the type of exercise. For example, some authors have observed that the practice of team sports increases the risk of substance use because it implies some level of socialization compared to individual sports (Bedendo, Andrade \& Noto, 2015). Regarding specificics on this consumption, the same authors found that professionals athletes consume less substances than amateur athletes, indicating that the frequency of practice influences the pattern of consumption. In Brazil, Bedendo, Opaleye, Andrade, and Noto, (2013) conducted a survey of more than 19,000 students and found a strong association between heavy drinking (binge) with the practice of amateur football among high school students.

The quality of the performed activity also seems to be another factor associated with substance use. Sharp et al. (2011) conducted a longitudinal study on three leisure experiences with 1,118 adolescents (boring experiences, new experiences and healthy experiences). The authors used the tool Leisure Experience Battery for Adolescents and found that those who engaged more frequently in activities considered tedious increased their chances of consumption by $36 \%$ (especially alcohol). The authors considered a specific activity score as boring $(0=$ strongly disagree, $4=$ strongly agree $)$ out of three instrument responses; 1) My free time is boring; 2) I generally do not like what I do during my free time, but do not know what could make it pleasurable; 3) for me, my time is idle and drags indefinitely.

Another interesting finding in this study is that the adolescents with a higher frequency of new or significantly healthy experiments used less 
psychoactive substances. The authors conclude that these data are important because they can support new intervention strategies and reduce harmful substance use during adolescence.

These findings, however, are not homogeneous because Weybright, Caldwell, Ram, Smith and Jacobs (2014) found strong association between drug use and pleasurable leisurely activities in a sample of approximately 5,800 students from 12 to 18 years and facing the controversial results, the association between use of drugs has not yet been investigated in Brazilian literature, from the studies found to date.

The objectives of this study were: 1) evaluate possible associations between PFL and substance use in adolescents; 2) evaluate the use of substances from different characteristics of leisure activities. We hypothesized that a) the use of substances, independent of frequency, would have effect on the PFL; b) the frequency of consumption influences the PFL; c) the PFL would be mainly affected in users of multiple substances.

\section{Method}

\section{Sample}

The sample $(\mathrm{N}=165)$ was composed both by adolescents who attended (information taken by the magazine) $(\mathrm{N}=50)$ and by a state school students in the city of Guarulhos-SP $(\mathrm{N}=115)$. The Quixote project arose from a program of tending to substance dependent users from the Department of Psychiatry at Universidade Federal de São Paulo. In this program, teens receive psychological and clinical psychiatric care, as well as integrated educational projects and professional monitoring. The inclusion criteria were; aged between 14 and 18, being patrons of the institutions described above and not showing visibly compromising physical and/or cognitive limitations. 21 adolescents in the sample were excluded due to their questionnaires having three or more PFL items unfilled, which would greatly compromise the data analysis.

\section{Instruments}

ABIPEME SCALE - This tool enables the socioeconomic classification of the participants with assigning scores to a set of domestic comfort items, in addition to the householder's education level.

DUSI (Drug Use Screening Inventory)- The instrument was developed to evaluate the pattern of drug use, especially in adolescents, and can be self administered. It has 149 questions divided into 10 areas. In this study, we used only the drug use frequency table which evaluates the frequency of use of substances during the last month. The instrument was translated, adapted and validated in Brazil by De Micheli \& Formigoni (2002) and showed $72 \%$ sensitivity and $97 \%$ specificity in the classification of adolescent substance users. The teenagers indicate the answer that corresponds to the number of times the substance was used in the last month: have not used, used 1-2 times, used 3-9 times, used 10 to 20 times, used more than 20 times. Anabolic steroids, tranquilizers, painkillers, opioids and phencyclidine were discarded due to low occurrence in the sample.

Leisure Diagnostic Battery (LDB) Short Form Version B- The instrument assesses the perception of competence, control, necessity and depth of involvement in leisure experiences (Ellis \& Witt, 1989). The combination of these constructs enables the evaluation of the PFL as a whole. This instrument was translated, adapted and validated to Brazil by Borges (2004) with high level of reliability (Cronbach's alpha $=0.81)$. The questionnaire has 25 questions with 5-point answers (Likert scale) to be marked according to the affirmative, ranging from complete agreement (5) to complete disagreement (1).

QSDL (Demographics and Leisure data questionnaire)- This instrument was adapted from Borges' study (2004) with the goal of collecting sociodemographic data and activities related to leisure. The answers relating to activities perceived as leisure (performed in the last three months) were categorized according to their nature with info from the data collected by the participants and based on previous studies (Borges, 2004; Dumazedier, 1976; Marcelino, 1998): Leisure Activities with emphasis on movement (ALM): sports, dance, cycling, walking, gymnastics, bodybuilding, fitness, body practices, crafts, draw, flykite, play guitar, marbles, tidy up the house, cooking. Leisure activities with an emphasis on observing (ALE): watch TV, movies, listening to music, studying, reading, riding a car, play dominoes, checkers. Leisure activities with an emphasis on virtual (ALV): internet, social networks, virtual games, computer; video game. Leisure activities with an emphasis on social interaction (ALS): Hanging out with friends, hanging out with parents, clubs, parties, going to parks, shopping malls; plays, church, stay out, dating, travel.

\section{Ethics}

This study was approved by the Research Ethics Committee (CEP number: 226.618, CAAE: 12227013.8.0000.5505) and all stages of the research 
followed the Resolution No. 01/88. All those adolescents who agreed to be part of the sample filled out the Consent Agreement and the parents filled out the Informed Consent Agreement.

\section{Data analysis}

We used a Chi-square test to analyze the categorical variables Student $\mathrm{t}$ or analysis of variance (ANOVA) for the variables. From the ANOVA significance test Scheffé was used to retrospectively evaluate the difference between the variables. As recommended by the American Psychological Association (Cumming, Fidler, Kalinowski \& Lai, 2012), when possible the confidence intervals $(C I \pm 95 \%)$ and effect size from Cramer's $V$ Test were presented. The interpretation of the effect sizes was based on Cohen (1988) and involved the following criteria: analysis with freedom degrees FD = 1 (0 to $0.1=$ slight effect $)(0.11$ to $0.3=$ medium effect $)$ ( 0.31 to 1 , high effect $) ; \mathrm{FD}=2$ ( $=0$ to 0.07 small effect $)$ $(0.08-0.21=$ average effect) $(0.22$ to 1 , high effect. The significance level was $5 \%$ in all analysis and used the SPSS 20.0 statistical software.

\section{Results}

The mean age of participants was 15.8 years $(\mathrm{SD}=1.81)$, and approximately $70 \%$ were from state schools and $30 \%$ of the Quixote project. As to gender we observed no differences, there was a slightly larger number of women, and most adolescents were consistent with the socioeconomic classes B or C (84\%) and very few were in shelters $(2 \%)$, according to Table 1.

Table 1

Description of sociodemographic data. Values expressed in number and percentage. the Confidence Interval (CI $\pm 95 \%)$ was expressed in \% divided by $100(\% / 100)$ and the size of the effect was calculated from Cramer's V Test. The analysis did not take the missing data into consideration.

\begin{tabular}{|c|c|c|c|c|c|}
\hline Variables & $\mathrm{N}(\%)$ & $95 \% \mathrm{CI}$ & $\mathrm{X}^{2} / \mathrm{F}$ & $p$ & Cramer's V \\
\hline Gender & & & 0.04 & 0.9 & 0.01 \\
\hline Female & $83(51.2 \%)$ & $0.42-0.58$ & & & \\
\hline Male & $79(48.8 \%)$ & $0.40-0.56$ & & & \\
\hline Missing data & 3 & & & & \\
\hline Ethnicity & & & 48.5 & 0.00 & 0.35 \\
\hline White & $46(35.1 \%)$ & $0.26-0.44$ & & & \\
\hline Black & $13(9.9 \%)$ & $0.05-0.16$ & & & \\
\hline Brown & $68(51.9 \%)$ & $0.43-0.6$ & & & \\
\hline Indigenous/Yellow & $4(3.1 \%)$ & $0.008-0.07$ & & & \\
\hline Missing data & 34 & & & & \\
\hline Social economic level & & & 30.3 & 0.00 & 0.31 \\
\hline Class A/B & $33(21.2 \%)$ & $0.15-0.28$ & & & \\
\hline Class C & $99(63.4 \%)$ & $0.55-0.71$ & & & \\
\hline Class D/E & $24(5.4 \%)$ & $0.02-0.1$ & & & \\
\hline Missing data & 9 & & & & \\
\hline Where most of the time is spent & & & 62.5 & 0.00 & 0.27 \\
\hline Home & $90(55.5 \%)$ & $0.47-0.63$ & & & \\
\hline Work & $38(23.4 \%)$ & $0.17-0.3$ & & & \\
\hline Street & $17(10.4 \%)$ & $0.06-0.16$ & & & \\
\hline School & $13(8.0 \%)$ & $0.04-0.13$ & & & \\
\hline Other & $4(2.4 \%)$ & $0.006-0.06$ & & & \\
\hline
\end{tabular}


For the marital status, mostly young people were single $(93 \%)$ and spent most of the time at home, then work, on the street and lastly only $8 \%$ stayed most of the time in school.

In regard to the type of leisure activities, 1.2\% were resting activities, 6.7\% touristic activities, 7.3\% manual activities, 9.1\% hedonistic activities, $12.0 \%$ artistic activities, $13.3 \%$ intellectual, $20.6 \%$ web/electronic games, $23.3 \%$ social activities, $41.8 \%$ physical. On the nature of the activities, $46.6 \%$ practiced leisure activities with emphasis on movement (ALM); 19.6\% practiced activities with emphasis on observing (ALE), $30 \%$ practiced activities with emphasis on socialization (ALS) and $20.3 \%$ practiced activities with an emphasis on virtual (ALV).

When assessed substance use, more than half of adolescents $(59.4 \%)$ had used one or more substances in the last month, with $43.6 \%$ having used only one type of substance, almost 16\% used two substances and 5.4\% over three. In relation to the use of specific substances, mostly alcohol was used (55\%), with $35 \%$ of the young having made recent use, and 10\% used heavily (1 to 9 times in the last month), $10.31 \%$ frequently, $9 \%$ heavy (over 20 times). On tobacco consumption, approximately $18 \%$ of the adolescents reported using tobacco in the last month, and of these, $12 \%$ used recently in the last month (1-9 times) and 5.5\% were heavy drinkers. The third most used substance was marijuana (12.7\%), of these, $10.3 \%$ had recent use (1 to 9 times), $0.6 \%$ used frequently (10 to 20 times) and $1.8 \%$ had used heavily (more than 20 times). With regard to cocaine and its derivatives, $1.8 \%$ had used recently last month. Regarding the ecstasy, only $2 \%$ of adolescents had used this substance (recent use).

Table 2 shows the frequency of substance use (based on the classification of DUSI) on the nature of the activities. Although the higher prevalence of nonusers has been in leisure activities with an emphasis on virtual environments (ALV), there were no significant differences between the types of leisure and frequency of substance use.

Table 3 shows the frequency of drug use in the last months for the different dimensions of the PFL (Perception of freedom in global leisure, Perception of needs in leisure, perception of competence in leisure; Perception of depth in leisure and Perception of control over leisure). Significant differences for most substances, except for the use of ecstasy and marijuana were detected. Regarding the ecstasy, there was a significant effect of the frequency of use on the global

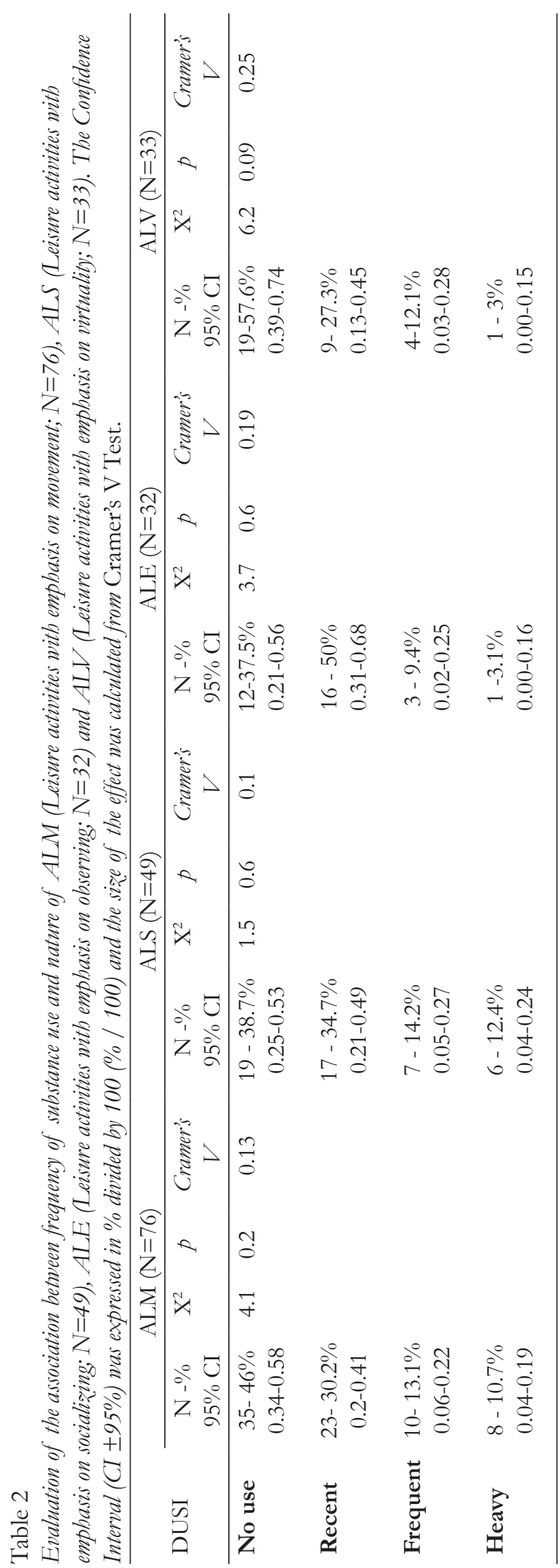


Table 3

Effect of frequent use and number of substances used in the past month over the Perception of Freedom in Leisure (PFL).

\begin{tabular}{|c|c|c|c|c|}
\hline Substance & $\begin{array}{c}\text { Dimensions of the Perception of } \\
\text { Leisure(PFL) }\end{array}$ & Sum of squares & F test & $p$ \\
\hline \multicolumn{5}{|l|}{ Alcohol } \\
\hline & PFLGlobal & 1.62 & 1.56 & 0.18 \\
\hline & Pneed & 1.94 & 1.30 & 0.27 \\
\hline & Pcomp & 0.99 & 0.69 & 0.59 \\
\hline & Pdepth & 1.80 & 1.30 & 0.27 \\
\hline & Pcontrol & 2.84 & 2.07 & 0.08 \\
\hline \multicolumn{5}{|c|}{ Crack/cocain } \\
\hline & PFLGlobal & 0.09 & 0.37 & 0.54 \\
\hline & Pneed & 0.30 & 0.82 & 0.36 \\
\hline & Pcomp & 0.07 & 0.21 & 0.64 \\
\hline & Pdepth & 0.00 & 0.01 & 0.91 \\
\hline & Pcontrol & 0.34 & 0.98 & 0.32 \\
\hline \multicolumn{5}{|l|}{ Ecstasy } \\
\hline & PFLGlobal & 2.04 & 2.66 & 0.05 \\
\hline & Pneed & 3.58 & 3.31 & 0.02 \\
\hline & Pcomp & 0.82 & 0.76 & 0.51 \\
\hline & Pdepth & 1.17 & 1.12 & 0.33 \\
\hline & Pcontrol & 4.31 & 4.33 & 0.00 \\
\hline \multicolumn{5}{|l|}{ Marijuana } \\
\hline & PFLGlobal & 1.86 & 1.80 & 0.13 \\
\hline & Pneed & 4.06 & 2.82 & 0.02 \\
\hline & Pcomp & 2.05 & 1.47 & 0.21 \\
\hline & Pdepth & 1.21 & 0.87 & 0.48 \\
\hline & Pcontrol & 2.00 & 1.43 & 0.22 \\
\hline
\end{tabular}

score (PFLGlobal) and on the Perception of need and control in leisure (Pcomp). Regarding marijuana, there was a significant difference only on the Pcomp component. To optimize the data analysis, taking into account the small number of users, we worked with the dichotomous variable (yes/no) for each substance used. Through these analyzes, we found that users of cocaine/crack had a higher perceived control $(\mathrm{t}=$ $-6.131 ; p<0.00)$.

When we assessed the association of both the number of substances used by the young and the usage frequency as components of the perception of leisure, no significant effects were observed (Table 4). To test whether the PFL sub-items could act as risk predictors of substance use, we observed that the perception of Need, Competence, Depth and Control have poor predictive capabilities based on the ENTER method (procedure that keeps all variables the model, being them significant or not) as described in Table 4.

\section{Discussion}

Among the major findings in this study, nearly $60 \%$ of users used one or more substance last month with the largest PFL index being associated with greater use of ecstasy and marijuana. Moreover, leisure 
Table 4

Sub items of the instrument do instrumento (Leisure Diagnostic Battery (LDB) Short Form - Version B) compared between non users, recent users, frequent and heavy users.

\begin{tabular}{|c|c|c|c|c|}
\hline & $\begin{array}{c}\text { Dimensions of the Perception } \\
\text { of Leisure(PFL) }\end{array}$ & Sum of squares & $\mathrm{X}^{2} / \mathrm{F}$ & $p$ \\
\hline \multicolumn{5}{|l|}{$\mathbf{N}^{\mathrm{o}}$ substances } \\
\hline & PFLGlobal & 0.38 & 0.47 & 0.69 \\
\hline & Pneed & 0.52 & 0.46 & 0.71 \\
\hline & Pcomp & 1.86 & 1.78 & 0.15 \\
\hline & Pdepth & 0.15 & 0.14 & 0.93 \\
\hline & Pcontrol & 0.76 & 0.71 & 0.54 \\
\hline \multicolumn{5}{|l|}{ Usage frequency } \\
\hline & PFLGlobal & 0.57 & 0.71 & 0.54 \\
\hline & Pneed & 1.06 & 0.94 & 0.41 \\
\hline & Pcomp & 0.58 & 0.54 & 0.65 \\
\hline & Pdepth & 1.73 & 1.68 & 0.17 \\
\hline & Pcontrol & 0.57 & 0.53 & 0.65 \\
\hline
\end{tabular}

activities with an emphasis on virtuality had the highest prevalence of nonusers and only $8 \%$ of teenagers spend most of their time in school. With regard to substances, there was a higher prevalence of alcohol consumption among teenagers and these data were similar to those found in other studies. Laranjeira, Madruga, Pinsky, Caetano, Ribeiro and Mitsuhiro (2013) observed that young people are consuming alcohol at increasingly earlier ages (average 13.9 years). Alcohol is the most consumed substance in Brazil and the increase in consumption has been observed in several countries. Thus it is possible that teens are drinking, regardless of their PFL indexes. In this sense, according to the National Survey on Alcohol and Drugs, approximately 50\% of Brazilian adolescents consumed alcohol heavily in the previous month and $16 \%$ drank on a binge, which is determined as the consumption of at least five doses over a period of two hours (Laranjeira et al., 2013).

Regarding marijuana we detected a trend as to its recreational use, but this use was two times higher than that seen in the southeast (Galduróz, Noto, Nappo, \& Carlini, 2004); $0.6 \%$ made frequent use and $1.8 \%$ made heavy use, close to the average found in the survey of 2004. The use of cocaine and crack was considered jointly, as few adolescents reported having consumed them (less than $2 \%$ ). In the present work we did not detect significant differences in relation to the effect of frequency of alcohol, hallucinogens and tobacco use on the global PFL and perceived need, control, competence and depth at leisure.

Furthermore, the teenagers who used amphetamines showed higher levels of perceived depth $(\mathrm{t}=$ -3.484, $\mathrm{p}=0.02$ ) when compared to the others. Thus, we can say that the use of amphetamine was related to the experience of flow, characterized by a deep state of excitement and enthusiasm as well as a distortion of time perception (Witt \& Ellis, 1989). Likewise, the group that mostly used inhalants had higher Competence Perception $(t=-2.597, p=0.036)$, which relates to a positive evaluation of one's own skills. Those who used crack/cocaine $(t=-6.131, p=0.006)$ had higher perception of control, attributing control over events to themselves. These findings contrast with some studies indicating deficits in social skills in substance users, according to the review by Wagner and Oliveira (2007).

However, it is important to consider two questions: most authors evaluate programs and test relationships between the skills to resist drug use associating them with assertiveness and management of conditions in which the young can find themselves. Thus, adolescents who use substances have "deficits" in resistance skills as they are users, which is not equivalent to say that these same adolescents have social skills impairments as a whole (problem solving, communication, assertiveness, 
etc.). Regarding the second question, it is necessary to distinguish the perception that the subject has on their own abilities over their actual skills. The findings of this research indicate that the group of substance users have a similar perception or higher than that of nonusers, over their own abilities.

For the use of cannabis, we noticed that the more frequent the use, the greater the perception of need in Leisure $(F=2.828 ; p=0.02)$. So, it's as if marijuana use (considering all the environmental variables, use, meaning, etc.) helps the teen to recognize and meet personal importance needs such as to make new friends friends, to be creative and to calm down. Taking an anti-drug culture into account, it is hard to admit the possible gains conferred to substance use, and it is not marijuana itself, but the assignment of positive significance to the event. The findings indicate that those adolescent marijuana users are perceived as better able to participate in self motivated experiences and enjoy the benefits derived from the satisfaction of socialization, catharsis, relaxation, excitement and expression needs.

The frequency of ecstasy use also had significantly positive effect in relation to Perception of Global Freedom in Leisure, Perception of Needs and Control in Recreation. Thus, we can hypothesize that the relation between the frequency of use and PFL has occurred because of; 1) higher number of exposures to context factors related to the personal satisfaction of needs mentioned at the time of use; 2) the psychobiological interference of substance use in judging the events that occur during leisure, bringing the teenager to feel "freer". According to the Attribution Theory, the pursuit or avoidance of leisure experiences comes from beliefs related to the causes of success or failure during the activities (Iso-Ahola, 2015). Thus, the effect of the substance would have been positively associated as "success factor" or greater freedom in leisure.

Another important finding is that leisure was not associated with participation in the categories of activities listed here. Over the past three months we found that the activities with emphasis on movement were held more frequently, followed by social and virtual/ electronic gaming activities. Activities of relaxation or contemplation, tourist activities, hedonistic, manual, artistic and intellectual were practiced by few teenagers. Therefore, it is possible that leisure with emphasis on observing or virtuality is associated with the use of psychotropic substances.

This hypothesis is based on studies indicating that the brain tends to search for new sensations and stimuli during adolescence more than on other life stages (Dahl, 2004). When you can not meet this demand through a daily life suitably enriched with new experiences, adolescents tend to seek other "clumsy" ways to excite themselves through the use of substances.

This study has some limitations, such as the fact that it was not possible to distinguish the impact of addiction, as a pathology important to mental health, on the PFL. Added to this, adolescents in more serious situations of abuse were not part of the sample, they are probably school dropouts, on the streets or disconnected from other institutions. Another point was to not exclude adolescents with possible psychiatric comorbidities belonging to Quixote Project, which also runs the CAPS II Quixote, which may also have affected the results. It is believed that other qualitative methods are capable of better approaching the subjective universe of adolescents in order to understand the contradiction between the perceived freedom, constraints, forms of participation, meanings and values that permeate the leisure phenomenon and drug use. Therefore, the picture of drug use is not made only by individual studies.

\section{Conclusion}

The findings indicate that the PFL as a state of mind can be influenced by drugs, taking into account also the interference of other unknown variables, which justifies the low predictive power of the PFL in the substance use. Moreover, the influence of specific components of the PFL on the frequency of substance use may be due to the greater number of exposure to situations of recreational use, not their neurobiological effect. We also found that the nature of the leisure activity (emphasis on movement, socialization, virtuality, observation) is not associated with substance use.

\section{References}

Aky1ldı-Munusturlar, M., \& Argan, M. (2016). Development of the serious and casual leisure measure. World Leisure Journal, 58, 124-141. doi: 10.1080/16078055.2015.1126759

Andrade, A.L.M, De Micheli, D., da Silva, E. A., Souza-Formigoni, M. L.O \& Goeldner, F. O. (2016). Neural Development in Adolescence Drug Abuse in Adolescence (pp. 23-33): Springer. doi: 10.1007/978-3-319-17795-3_3 
Appel-Silva, M., Welter Wendt, G., \& Iracema de Lima Argimon, I. (2010). A teoria da autodeterminação e as influências socioculturais sobre a identidade. Psicologia em Revista, 16, 351-369. Retrieved from: http://periodicos.pucminas.br/index.php/psicologiaemrevista/article/ download/P.1678-9563.2010v16n2p351/1942

Bedendo, A., Opaleye, E. S., Andrade, A. L.M, \& Noto, A. R. (2013). Heavy episodic drinking and soccer practice among high school students in Brazil: the contextual aspects of this relationship. BMC Public Health, 13, 247. doi: 10.1186/1471-2458-13-247

Bedendo, A., Andrade, A. L. M, \& Noto, A. R. (2015). Prática esportiva e uso de substâncias entre estudantes do ensino médio: diferentes perspectivas dessa relação. SMAD. Revista eletrônica saúde mental álcool e drogas, 11, 85-96. doi: 10.11606/issn.18066976.v11i2p85-96

Blank, C., Leichtfried, V., Schobersberger, W., \& Möller, C.. (2015). Does leisure time negatively affect personal health? World Leisure Journal, 57, 152-157. doi: 10.1080/16078055.2015.1027874

Borelli, S. H. S. (2000). Jovens em sao Paulo Lazer, consumo cultural e habitos de ver TV. Nómadas (13), 92-97. Retrieved from: http://www.redalyc.org/ pdf/1051/105115264008.pdf

Borges, K. E. L. (2004). Influência da atividade física na qualidade de vida dos sujeitos com transtornos mentais. (Tese de Doutorado), Universidade do Porto, Portugal. Retrieved from: https: / / repositorio-aberto.up.pt/bitstream/10216/9725/3/5649_TD_01_P.pdf

Caldwell, L.L, \& Witt, P.A. (2011). Leisure, recreation, and play from a developmental context. New directions for youth development, 2011, 13-27. doi: 10.1002/yd.394

Carruthers, C.P. (1993). Leisure and alcohol expectancies. Journal of Leisure Research, 25, 229. Retrieved from: http:/ / connection.ebscohost.com/c/articles/ 9312080477/leisure-alcohol-expectancies

Clark, S. L., Gillespie, N. A., Adkins, D. E., Kendler, K. S., \& Neale, M. C. (2016). Psychometric modeling of abuse and dependence symptoms across six illicit substances indicates novel dimensions of misuse. Addictive behaviors, 53, 132-140. doi: 10.1016/j.addbeh.2015.10.015
Costa, Carmen. (2008). Percep̧̧ão de liberdade no lazer: perspectiva dos trabalhadores de saúde mental dos centros de referência e centros de convivência do município de Belo Horizonte. (Dissertação de Mestrado), Universidade do Porto, Portugal. Retrieved from: https://sigarra.up.pt/flup/pt//pub_geral. pub_view?pi_pub_base_id=22463

Csikszentmihalyi, M., \& Csikszentmihalyi, I.S. (1992). Optimal experience: Psychological studies of flow in consciousness: Cambridge university press.

Cumming, Geoff, Fidler, Fiona, Kalinowski, Pav, \& Lai, Jerry. (2012). The statistical recommendations of the American Psychological Association Publication Manual: Effect sizes, confidence intervals, and meta-analysis. Australian Journal of Psychology, 64(3), 8. doi: 10.1111/j.1742-9536.2011.00037.x

De Micheli, D., \& Souza-Formigoni, M.L.O. (2002). Psychometric properties of the Brazilian version of the Drug Use Screening Inventory. Alcoholism: Clinical and Experimental Research, 26, 1523-1528. doi: 10.1111/j.1530-0277.2002.tb02451.x

Dias, G. P., \& Santos, M.S. (2011). Trabalho e lazer na infância e adolescência no século XXI: direito social ou inclusão excludente? Motrivivência, 23, 291-305. doi: 10.5007/2175-8042.2011

Dumazedier, J. (2008). Sociologia Empírica do Lazer. São Paulo: Perspectiva. SESC.

Dumazedier, J. (1976). Lazer e Cultura Popular. São Paulo: Perspectiva. SESC.

Ellis, G.D., \& Witt, P.A. (1994). Perceived freedom in leisure and satisfaction: Exploring the factor structure of the perceived freedom components of the leisure diagnostic battery. Leisure Sciences, 16, 259270. doi: 10.1080/01490409409513236

Ellis, G.D., \& Witt, P.A. (1989). The leisure diagnostic battery users manual. State College, PA: Venture Publishing, Inc.

Ernst, M. (2014). The triadic model perspective for the study of adolescent motivated behavior. Brain and cognition, 89, 104-111. doi: 10.1016/j. bandc.2014.01.006

Ertuzun, E. (2015). Effects of leisure education programme including sportive activities on perceived freedom in leisure of adolescents with intellectual disabilities. Educational Research and Reviews, 10, 2362-2369. doi: 10.5897/ERR2015.2395 
Galduróz, J.C.F., Noto, A.R., Nappo, S.A., \& Carlini, E.A. (2004). Trends in drug use among students in Brazil: analysis of four surveys in 1987, 1989, 1993 and 1997. Brazilian Journal of Medical and Biological Research, 37, 523-531. doi: 10.1590/ S0100-879X2004000400009

Iso-Ahola, S.E. (2015). Conscious versus Nonconscious Mind and Leisure. Leisure Sciences, 37, 289-310. doi: 10.1080/01490400.2015.1005560

Kuykendall, L., Tay, L., \& Ng, V. (2015). Leisure engagement and subjective well-being: A metaanalysis. Psychological bulletin, 141, 364. doi: 10.1037/ a0038508

Laranjeira, R., Madruga, C. S., Pinsky, I., Caetano, R., Ribeiro, M., \& Mitsuhiro, S. (2013). II Levantamento Nacional de Álcool e Drogas-Consumo de Álcool no Brasil: Tendências entre 2006/2012. São Paulo: Inpad. Retrieved from:: http://inpad. org.br/wp-content/uploads/2014/03/Lenad-IIRelat $\%$ C3\%B3rio.pdf

Leversen, I., Danielsen, A. G., Birkeland, M. S., \& Samdal, O. (2012). Basic psychological need satisfaction in leisure activities and adolescents' life satisfaction. Journal of Youth and Adolescence, 41, 1588-1599. doi: 10.1007/s10964-012-9776-5

Lomeo, R.C. (2011). Percepşão de liberdade no Lazer de Familiares dos Usuários dos certos conveniencia de Belo Horizonte, Brasil. (Dissertação de Mestrado), Universidade do Porto, Portugal. Retrieved from: http://hdl.handle.net/10216/56815

Lomeo, R.C., Brandã, I.R.,\& Borges, K.E.L. (2007). Percepção de liberdade no lazer dos clientes do CAPS-sobral com transtornos de ansiedade e de humor. SANARE, 6, 5. Retrieved from: http:/ / sanare. emnuvens.com.br/sanare/article/view/154/146

Marcellino, N.C. (1998). Lazer e Educação. $5^{a}$ edição, Campinas: Papirus.

Neulinger, J. (1990). The road to Eden, after all: A buman metamorphosis: Giordano Bruno Culeborg, The Netherlands.

Noto, A. R., Galduróz, J. F.C, Nappo, S. A., Fonseca, A.M., Carlini, C.M.A., Moura, Y.G, \& Carlini, E.A. (2003). Levantamento nacional sobre o uso de drogas entre crianças e adolescentes em situação de rua nas 27 capitais brasileiras. São Paulo: Centro Brasileiro de Informações Sobre Drogas
Psicotrópicas. Retrieved from: http://www.cebrid. com.br/levantamento-nacional-sobre-o-uso-dedrogas-entre-criancas-e-adolescentes-em-situacaode-rua-nas-27-capitais-brasileiras-2003/

Oliveira, M.A.F, Gonçalves, R. M.D, Claro, H.G., Tarifa, R.R., Nakahara, T.B, \& Silva, N.N. (2016). Perfil das crianças e adolescentes em situação de rua usuários de drogas. Journal of Nursing UFPE on line. 10, 475-484. doi: 10.5205/01012007

Pinheiro, O. B., Andrade, A. L. M., \& De Micheli, D. (2016). Relação entre os níveis de atividade física e qualidade de vida no uso de drogas em adolescentes. SMAD. Revista Eletrônica Saúde Mental Álcool e Drogas, 12, 178-187. doi: 10.11606/issn.1806-6976. v12i3p178-187

Plate, R.C, Richards, J.M, \& Ernst, M. (2016). FMRI Studies of the Adolescent Reward System: The Triadic Model Perspective. Drug Abuse in Adolescence (pp. 113-136): Springer. doi: 10.1007/978-3-319-17795-3_8

Poulsen, A. A., Ziviani, J. M., \& Cuskelly, M. (2007). Perceived freedom in leisure and physical coordination ability: impact on out-of-school activity participation and life satisfaction. Child: Care, Health and Development, 33, 432-440. doi: 10.1111/j.1365-2214.2007.00730.x

Powrie, B., Kolehmainen, N., Turpin, M., Ziviani, J., \& Copley, J. (2015). The meaning of leisure for children and young people with physical disabilities: a systematic evidence synthesis. Developmental Medicine \& Child Neurology, 57, 993-1010. doi: 10.1111/ dmcn.12788

Sanchez, Z.M., Martins, S.S, Opaleye, E.S, Moura, Y.G., Locatelli, D.P, \& Noto, A.R. (2011). Social factors associated to binge drinking: a cross-sectional survey among Brazilian students in private high schools. BMC Public Health, 11, 1. doi: 10.1186/1471-2458-11-201

Sharp, E. H., Coffman, D. L., Caldwell, L. L., Smith, E. A., Wegner, L., Vergnani, T., \& Mathews, C. (2011). Predicting substance use behavior among South African adolescents: The role of leisure experiences across time. The International Journal of Behavioral Development, 35, 343-351. doi: 10.1177/0165025411404494

Silva, D. R., Fernandes, R. A., Ohara, D., Collings, P. J., Souza, M. F., Tomeleri, C. M., Cyrino, E. S. (2016). 
Correlates of sports practice, occupational and leisure-time physical activity in Brazilian adolescents. American Journal of Human Biology, 28, 112-117. doi: 10.1002/ajhb.22760

Soldera, M., Dalgalarrondo, P., Corrêa-Filho, H.R., \& Silva, C.A.M. (2004). Uso de drogas psicotrópicas por estudantes: prevalência e fatores sociais associados. Revista de Saúde Pública, 38, 277-283. doi: 10.1590/S0034-89102004000200018

ter Bogt, T. F., Gabhainn, S. N., Simons-Morton, B. G., Ferreira, M., Hublet, A., Godeau, E., the, Hbsc Peer Culture Focus Groups. (2012). Dance is the new metal: adolescent music preferences and substance use across Europe. Substance Use \& Misuse, 47, 130-142. doi: 10.3109/10826084.2012.637438

Van Havere, T., Vanderplasschen, W., Lammertyn, J., Broekaert, E., \& Bellis, M. (2011). Drug use and nightlife: more than just dance music. Substance Abuse Treatment, Prevention, and Policy, 6, 18. doi: 10.1186/1747-597X-6-18

Wegner, Lisa. (2011). Through the lens of a peer: Understanding leisure boredom and risk behaviour in adolescence. South African Journal of Occupational Therapy 41, 6. Retrieved from: http://www.sajot. co.za/index.php/sajot/article/view/15/21

Weybright, E. H., Caldwell, L. L., Ram, N., Smith, E. A., \& Wegner, L. (2015). Boredom Prone or Nothing to Do? Distinguishing Between State and Trait Leisure Boredom and its Association with Substance Use in South African Adolescents. Leisure Sciences, 37(4), 311-331. doi: 10.1080/01490400.2015.1014530

Weybright, E. H., Caldwell, L. L., Ram, N., Smith, E., \& Jacobs, J. (2014). The Dynamic Association between Healthy Leisure and Substance Use in South African Adolescents: A State and Trait Perspective. World Leisure Journal, 56, 99-109. doi: 10.1080/16078055.2014.903726

Witt, P. A., Ellis, G. D. (1999). The Leisure Diagnostic Battery: User Manual. Venture Publisher. Inc.

Recebido em: 22-03-2016 Reformulado em: 31-10-2016; 23-02-2017 Aprovado em: 08-03-2017 
Sobre os autores:

Diego Eugênio Roquette Godoy Almeida is graduated in Occupational Therapy and obtained his Master's degree from Federal University of Sao Paulo. Currently, he is Assistant Professor at Departament of Management and Health Care from Universidade Federal de São Paulo.

Email: diego.godoy@yahoo.com.br

André Luiz Monezi Andrade is graduated in Psychology and he is Professor from Pontifícia Universidade Católica de Campinas. He obtained his Master's degree and Ph.D. from Universidade Federal de São Paulo.

Email: andre.andrade@puc-campinas.edu.br

Fernanda Davidoff Cruz is graduated in Psychology and obtained his Master's degree from Universidade Federal de São Paulo.

Email: fdavidoff@uol.com.br

Denise de Micheli is graduated in Psychology and an Adjunct Professor from the Universidade Federal de São Paulo, Department of Psychobiology. She obtained her Master's degree and Ph.D. from Universidade Federal de São Paulo. Currently, she is head of Interdisciplinary Center for Studies in Neuroscience, Health, and Education in Adolescence (CIENSA) that is registered in CNPq. Besides, she is a member of AMERSA (Association for Medical Education and Research in Substance Abuse) and ABRAMD (Brazilian Association of Multidisciplinary Drug Studies).

Email: demicheli.unifesp@gmail.com

\section{Contato com os autores:}

André Luiz Monezi Andrade

Centro de Ciências da Vida. Pontifícia Universidade Católica de Campinas

Av. John Boyd Dunlop - Jardim Ipaussurama

Campinas-SP, Brazil.

Zip code: 13034-685 